\title{
Early 19th Century Translations in Hindustani/Hindi/Urdu and the Question of 'National Language'
}

\author{
MANOJ KUMAR YADAV
}

Some of the early works in modern Hindi and Urdu, like many other modern Indian languages, were produced by the missionaries and by the scholars at the college of Fort William. The College not only attempted to procure manuscripts but also appointed native scholars to produce texts in Hindustani. These texts were intended to be used to train the (non)commissioned company officers and 'men of the British army', serving in Bengal and Bombay presidencies, in the native languages. Of all these texts Premsagar and Bagh-O-Bahar occupy a significant place not only because they were prescribed texts to teach the officials but also because they seem to have introduced two particular ways of using Hindustani.

Bagh-O-Bahar was originally written in Persian under the title Ghasseh-e Chahar Darvesh [The Tale of the Four Dervishes] by the $13^{\text {th }}$ century poet Amir Khusro and it was translated into 'Urdu' by Mir Amman, an employee at the Fort William College. Later, it was translated into English by Duncan Forbes in 1857. Similarly, Premsagar was translated by Lalluji Lal in 1810 as Premsagar or The History of Krishn according to the Tenth Chapter of Bhagubut of Vyasudev. He translated it from 'Braj Bhasha of Chaturbhuj Mishra' into Hindi. In this article, I wish to look at different translations of the two works and the purposes they served in the nineteenth century. I will also attempt to understand how these translations contributed to a debate around 'national language' at that time.

Keywords: national language, Bagh-O-Bahar, Hindustani, Urdu.

\section{Introduction}

The facade of 'Hindi' and 'Urdu' as two different languages conceals a whole lot of other factors which have gone into the making of their present form. This consists of works of missionaries, educational institutions, voluntary and government organizations, publishing houses, print and journalism. A whole host of writings is available on what could be called the 
repressive past of 'Hindi' and 'Urdu'. Though it is difficult to pinpoint when and how the division, if it did, happen between 'Hindi' and 'Urdu', it is possible to trace the time from when the terms 'Hindi' and 'Urdu' started being employed in projecting two different linguistic idioms. A number of works can be cited to outline not only the early usage of the terms but also the early literary works under the tutelage of these two categories. However, I have limited this study to two supposed representative texts Bagh-O-Bahar and Premsagar in 'Urdu' and 'Hindi' respectively. I intend to look at the translations and the para-texts of these two works and the issues that ensue.

I aim to examine three key issues in this paper-the objectives behind the usage of Bagh-O-Bahar and Premsagar as language proficiency textbooks at the College of Fort William and the consequences of this expertise, the functions of different translations of these textbooks in the evolution and consolidation of two different styles of Hindustani, and the role of these translations in the debates on 'national language'.

\section{Discussion}

Prior to establishment of Fort William College, the British administrators willing to learn Hindustani depended primarily on dictionaries, grammars, language manuals and native munshis. With the establishment of Fort William College, a plan was laid out to train the young servants of the East India Company in the Indian languages. Hindi and Urdu were not seen as the two distinct language categories. In fact, these terms were not much in vogue and 'Hindustani' was the common term used by the Europeans to refer to the language of North India. The department of Hindustani came into existence in 1801 , but there was no department of Hindi until 1825. The department of Hindustani produced a number of works under the titles of Khari Boli, Braj, Hindustani, Urdu, and Hindi. However, the last two categories were increasingly employed only after 1830s.

Though a number of Hindustani works were produced at the college, a few of them gained considerable attention and popularity. Bagh-O-Bahar and Premsagar were published in 1805 and 1810 respectively. Both of these works were central to the learning of Hindustani and were held by many Europeans in high esteem. In 1846, Duncan Forbes ${ }^{1}$ wrote about Bagh-OBahar:

The Bagh-O-Bahar is universally allowed to be the best work that has been yet composed in the Hindustani language. For nearly half a century it has maintained its pre-eminence as a textbook for the examination of the Company's junior servants (Forbes 1846: 03).

\footnotetext{
${ }^{1}$ Duncan Forbes was a Scottish linguist who attended the Calcutta Academy from 1824 to 1826. When his poor health forced him to return to London in 1826, he became an assistant to Gilchrist. Later he worked with Sandford Arnot on early Hindustani dictionaries.
} 
Edward Backhouse Eastwick ${ }^{2}$, writing around the same time, observes in his grammar titled A Concise Grammar of the Hindustani Language (1847) that 'The best specimen of Hindustani with which we are acquainted is the Bagh-O Bahar'. Similarly, Captain William Hollings ${ }^{3}$ in his translation of Premsagar in 1848 calls 'the Hindi of Prem Sagur as remarkably pure', hence it was a suitable text for learning Hindi. It is not surprising that both of these works went through a number of editions until the end of nineteenth century. In addition to this, these textbooks, to a certain extent, served as a model for the preparation of other textbooks such as, Rajneeti (1827), Tota Kahani (1862) Sabha Bilas (1828), Khriad Afroz (1867), Ikhwan-us-Safa (1869), Baital Pachisi (1855), Ramayan (1877) etc.

However, by the end of nineteenth century, the tide seems to have taken an obverse turn as the efficacy and relevance of Bagh-O-Bahar and Premsagar were questioned by many scholars. Charles Trevelyan writing in 1858 says that the language of both works were 'pedantic, puerile and licentious', and recommended that, 'it should be discarded as a text-book, and manuals should be compiled more closely representing the actual language of the camp and country. ${ }^{4}$

These primary observations lead us to a set of questions-why did the translators employ such language in their translations which was not the 'actual language' of the masses? Whether translators were instructed to do so by their colonial masters or it was their independent decision? Did the translations, commissioned at Fort William College, serve only the pedagogical purposes?

Taking first two questions into account, we can see that observations made by G. A. Grierson in his works titled The Satsaiya of Bihari (1896), suggests that John Borthwick Gilchrist, who was also the principal of the college, had something to do with it:

Although bearing now and then traces of the Gujrati influences of his origin, Lallu-Ji-Lal's style, both in Hindi and in Braj bhakha, is deservedly popular. The former language may be said to have been invented by him at the instigation of Gilchrist. That gentleman wanted an Urdu book written, with all Arabic and Persian words excluded, their places being taken by Hindu words. Such a language did not exist in India before. Urdu has been used to some degree, as a vehicle of literature, by Musalmans, and was the lingua franca of

\footnotetext{
${ }^{2}$ Edward Backhouse Eastwick served as professor of Hindustani from 1845 to 1850 at Hailebury College, where Hindustani was taught as a language to the officers of British army. He was a renowned linguist and wrote grammars of Sanskrit and Hindustani in 1845 and 1847 respectively.

${ }^{3}$ William Hollings was Captain in the $47^{\text {th }}$ Regiment of the Bengal Native Infantry. He translated Premsagar (1848) and Baital Pachisi (1866) into English for the British army officers to learn Hindustani.

${ }^{4}$ For details see The Letters of Indophilusto "The Times", p.17.
} 
the Bazaar. Hindus spoke their own local dialects, Braj, Kanauji, Marwari, Bhojpuri, and so on. Urdu was nowhere the language of any locality or any nation. It was simply a broken mixture of half a dozen Indian dialects, used by the Mughul conquerors in their interaction with natives, and larded freely with foreign, Arabic and Persian words. Gilchrist made the initial mistake of supposing that it was a national language, and he attempted to restore it to what he imagined must have been its original Hindi form. By turning out all the Arabic and Persian words, and substituting Hindi ones (Grierson 1896: 12).

A large number of words used in the different Hindi-Urdu translations of Bagh-O-Bahar and Premsagar were, and still are, present in both the languages, but they were kept mutually exclusive in the translations (see the appendix). However, this is not to say that the translators and the colonial masters at the College of Fort William are only to be held accountable for the fissures that surfaced later. The growing Hindu-Muslim antagonism in the second half of nineteenth century, the Hindi Urdu controversy of 1860s, the failure of 1857 rebellion and the British analysis of Muslims as chief conspirers of the 'mutiny', etc. were also, among others, the reasons which aggravated the divide. However, I do not intend to look at this aspect of the issue here.

Moreover, if we look at the translations of Bagh-O-Bahar and Premsagar, it is very clear that they do not serve pedagogical purposes only. They were also instrumental in establishing the colonial narratives of language origin, which was the larger objective of the Orientalist project. Lewis Ferdinand Smith's translation of Bagh-O-Bahar, titled The Tale of the Four Durwesh, translated from the Oordoo tongue of Meer Ummun, of Dhailee (1811), is a typical example of such practice. The section 'preface by the translator' states about the work:

....The work itself is the best and the most correct that has been composed in the Oordoo language; a language which is both dulcet and elegant, and which was little known to Europeans until zeal, labour and talents of Mr. Gilchrist open to us a perfect path to acquire it. Moreover, the Bagh O Buhar is a classical work in the College of Fort William; it highly deserves its distinguished fate, as it contains various modes of expression in correct language; it displays a great variety of Eastern manners and modes of thinking, and it is an excellent introduction not only to the colloquial style of Hindustan, but to a knowledge of its various idioms (Smith 1850: $03)$.

A few observations which emerge out of the above excerpt are:

1. It proposes the possibility of different idioms available under an allinclusive term 'Hindustani'. 
2. The translator operates with the concepts of 'correct' and 'faulty' language and colloquial and standard styles of the same language.

3. Urdu represents not only the colloquial style of Hindustani but also its different varieties.

4. Further, description about the emergence of a certain mixed language is continued in Smith's translation. Again, this too can be viewed possibly as a constructionist narrative of the Urdu language.

When Ukbur ascended throne, then all casts of people, from all countries learning of his goodness, justice, and liberty, and those of his unequalled family flocked to his court. Though the tongue of each was different, yet by being assembled together, they used to traffic and do business and converse with each other; from which mixture of tongues arose the Oordoo language (ibid.11).

My concern, here, has not been to find out whether the above narratives were fact or fiction. I have rather restricted myself to understand the ways these narratives shaped different translations of the two works. Translations were crucial in showing the realistic possibility of using Hindustani in two ways, which later led to an official divide between Hindi and Urdu. By the end of nineteenth century Bagh-O Bahar and Premsagar had already been established as the two representative texts of Hindus and Muslims respectively.

A common recurrence that we can notice in both the texts is the concepts of 'mixed language' and 'pure language'. And both the texts seem to be working towards achieving a 'pure language'. For instance, in the preface of his translation of Premsagar, Lalluji Lal states that while translating the original text, he rejected the foreign language of the Yavans, and turned the source text into 'pure language' of Delhi and Agra. ${ }^{5}$ Whereas, Adalut Khan, in his translation of both the texts titled Selections from the Premsagar and Bagh- $O$ Bahar in 1881, terms the translation done by Captain Hoolings 'a fairy tale' for rendering a free translation of the text. Also, he considers the translation incomprehensible for retaining too many Braj Bhasha words (Khan 1881: 03).

In addition to this, by the end of nineteenth century these texts, along with so many other translations of the similar kind, seem to have introduced a fixed notion of association of a language with a particular script-Devanagari for Hindi and Persian for Urdu. Specifically in the second half of nineteenth century, the issue of script becomes very significant. Very frequently, Premsagar and Bagh- $O$ Bahar, except their English translations, were published in Devnagari and Persian scripts respectively. Perhaps these practices, which can be further traced into many translations happening

\footnotetext{
${ }^{5}$ Another work written on the similar lines, i.e. by discarding the language of Yavans, is a short story titled Rani Ketaki Ki Kahani (c.1803) by Insha Allah Khan.
} 
during this period, along with other socio-political developments, played a vital role in the emergence of Hindi and Urdu in its present form.

\section{Quest for the 'National Language'}

An important issue that has occupied the attention of scholars, specifically in the latter of half of the $19^{\text {th }}$ century, is the issue of the national language. Colebrooke $^{6}$, in his article "Sanscrit and Pracrit Languages", terms all the regions such as Mithila, Canyacubja (Kannauj), Utcala, Dravida, Maharashtra, Carnata (Karnataka), Tailanga etc. as 'nations'. Colebrooke also seems to suggest that the languages spoken in these areas were independent languages. The term 'national language' in the Indian context, in its modern sense was used relatively later. J. R. Ballantyne (1813-1864), principal of the department of English at Banaras College, was probably one of the first Oriental scholars to urge the 'brother Pundits' to work towards a 'national language'. Ballantyne also suggests that the 'dialect of Benares' could be developed, as the standard variety (General Report on Public Instruction in the North Western Provinces, 1846-47: 33). Ballantyne was trying to reiterate that one of the dialects of Hindi should be standardized first, and then it should be developed as the 'national language' of the country. By standardization, he meant improvement in three areas-creations of standard literature in one variety, a uniform system of grammar and orthography. The major obstacle in achieving the national language, as Ballantyne observes, was the diversity of 'provincial dialects', which, according to Ballantyne, need to be got rid of.

The issue of the national language was once again the focal point of debate between John Beames and F.S. Growse. While Beames advocates Hindustani or Urdu for its richness in having words from Arabic, Persian and Turkish, Growse dismisses Hindustani or Urdu for the same reason. Growse in his article titled "Some objections to the modern Style of official Hindustani" strongly proposes Hindi as the national language by highlighting the artificiality and the 'unnatural origin' of the Urdu language (Growse 1867: 181). He calls Urdu to be artificial because, according to Growse, it was created by munshis at the college of Fort William. He specifically criticizes the language of $\mathrm{Bagh}-\mathrm{O}$-Bahar as it did not have the potential to be developed as a language of a large section of the society.

What is common about propositions made by Beames and Growse is an anxiety to find a common language which could be understood in the entire North India, a national language. This tendency becomes more articulate in the debates between two other scholars writing at that time namely

\footnotetext{
${ }^{6}$ Colebrooke was an important figure whose engagements with Indology had bearings on the Oriental as well as native scholarship in the $19^{\text {th }}$ century. He was a scholar of Sanskrit and Persian. His translation of Bible into Persian was published in 1804 and he published a grammar of Sanskrit in 1805. He worked as a Professor of Hindu Law and Sanskrit at the College of Fort William.
} 
Shyamacharan Ganguli and George Abraham Grierson. Ganguli, while recognizing the existence of different regional varieties, envisions a special role for Hindustani at the national level. Whereas, Grierson seems to suggest that Hindustani still had a long way to go to make claims for the national status. Hence, he advocates the case of Bihari languages (Maithili, Bhojpuri and Magadhi) and opines that any of these languages could be developed as standard variety.

The most crucial element in this quest for national language is the development of a hierarchy which presupposes the role of regional varieties as subservient to the 'national language'. As a result of this development, Hindi starts being used as an overarching category for a large number of languages spoken across North India.

It can be said that transmutations, in the case of the two texts I have chosen for my study, correspond to the larger socio-political metamorphosis that the north Indian society was witnessing. The events such as, removal of Persian and the following replacement by 'vernaculars' in the Presidencies of Bombay and Madras in 1832, foundation of Arya Samaj in 1875 to restore the Vedic 'glory' of Hindus, foundation of Nagari Pracharini Sabha ${ }^{7}$ (Society for the Propagation of Nagari) of Benares in 1893 to promote the Devnagari script, MacDonnell's resolution that gave Nagari equal status with Urdu script in $1900^{8}$, foundation of Hindi Sahitya Sammelan in 1910 to project 'Hindi' as the national language, Congress' acceptance of Hindustani as the official language in 1925 are the samples of this metamorphosis. The translations of Bagh O Bahar and Premsagar were followed a number of other translations modelled on these two translations. This practice, on one hand, created an artificial divide between the two varieties of Hindustani, and on the other hand started a never ending debate around the prospective 'national language'. In such socio-political turmoil, translations can be seen not only as an indicative of the shifting debates on languages/language varieties but also as a means to establish the history and the location of the same.

\footnotetext{
${ }^{7}$ Nagari Pracharini Sabha was started in a small building of Queens Collegiate School at Benares. It was initially run as debating club by several school boys. However, later, writers such as Shyam Sundar Das, Ram Narayan Mishra and Shiv Kumar Singh came to be known as the founding members of the society. For details see King, (1994:141-143).

${ }^{8}$ Sir Antony MacDonnell was appointed the Lieutenant-Governor of North Western Province and Oudh in 1895. At the time Urdu in Persian script was the language of courts and offices of the province. But on $18^{\text {th }}$ April 1900, MacDonnell issued an order allowing the permissive use of Devnagari script in the courts and the offices of the province. For a detailed account see Rai (2001: 17-49) and King (1993: 148-156).
} 


\section{Appendix}

A very short list of Hindi and Urdu words used in the different translations of Bagh-O-Bahar and Premsagar

\begin{tabular}{|c|c|c|c|}
\hline \multicolumn{2}{|c|}{ Bagh-O-Bahar } & \multicolumn{2}{|c|}{ Premsagar } \\
\hline Hindi-1882 & Urdu-1859 & Hindi-1882 & Urdu-1886 \\
\hline Yogi & Durvesh & Aakhet & Shikargah \\
\hline Deshatan & Ser & Raja & Hakim \\
\hline Kahani & Qissa & Antardhyanhona & $\begin{array}{l}\text { Nazar se nihan } \\
\text { hona }\end{array}$ \\
\hline Shuru & Aghaz & Mahadukh & Bala-e azeem \\
\hline Dani & Sakhawat & Bita & Guzara \\
\hline Samay & Waqt & Rishi & Fakeer \\
\hline Paripoorn & Mamur & Shaap & Baddua \\
\hline Kosh & Khazana & Prem & Ulfat \\
\hline Sena & Lashkar & Saptah & Hafta \\
\hline Kapaat & Darwaaza & Dharati & Zameen \\
\hline Pathik & Rahi Musafir & Taquat & Istikamat \\
\hline Grih & Ghar & Shanti & Aman \\
\hline Desh & Mulk & Vyast & Mushthail \\
\hline Adheen & Amalmein & Prasthankiya & Gaya \\
\hline Putra & Farzand & Saanp & Maar \\
\hline Sandehyukta & Fikrmand & Dhyan se & Gaur se \\
\hline Ishtadeva & Allah & Kewaaste & Keliye \\
\hline Daya & Inayat & Awastha & Kaifiyat \\
\hline Abhilasha & Arman & Aadat & Fitarat \\
\hline Darpan & Aaina & & \\
\hline Sandesh & Paigham & & \\
\hline
\end{tabular}

\section{References}

Amman, Mir. 1804. Bagh O Buhar. A Translation into the Hindoostanee Tongue, of the Celebrated Persian Tale, entitled Qissui Chuhar Durwesh by Meer Ummun. Translated by John Borthwick Gilchrist. Calcutta: Hindoostanee Press. 
AMMAN, MIR. 1874. Bagh O Bahar; or Tales of the four Darweshes. Translated from the Hindustani of Mir Amman of Dihli. Translated by Duncan Forbes. London: Wm. H. Allen \& Co.

AMMAN, MIR. 1850. The Tale of the Four Durwesh, translated from the Oordoo Tongue of Meer Ummun, of Dhailee. Translated by Lewis Ferdinand Smith. Calcutta: P. S. D'rozario and Co. Tank-Square.

AMMAN, MIR. 1882. Chahara Darawesh. Translated by Jeevaram Jaat. Lucknow: Nawal Kishore Press.

AMman, Mir. 1901. The Bagh O Bahar. Translated by Colonel W. Quentin. Calcutta: The Baptist Mission Press.

AMMAN, MiR. 1846. Bagh O Bahar; or Tales of the Four Darweshes. Translated by Duncan Forbes. London: Wm. H. Allen \& Co.

Colebrooke, H. T. 1803. On the Sanscrit and Pracrit Languages. Asiatick Researches; or Transactions of the Society Instituted in Bengal 7.199-231.

EASTWICK, EDWARD BACKHOUSE. 1847. A Concise Grammar of the Hindustani Language. London: James Madden, 8 Leadenhall Street.

GRIERSON G. A. 1896. The Satsaiya of Bihari with a Commentary entitled Lala-Chandrika. Calcutta: Office of the Superintendent of Government Printing.

Growse, F. S. 1866. Some Objections to the Modern Style of Official Hindustani. The Journal of Asiatic Society of Bengal. XLV: Part1:1-29.

KHAN, AdAluT. 1881. Selections from the Prem Sagar and Bagh-O Bahar. Calcutta: Baptist Mission Press.

KING, CHRISTOPHER. 1994. One Language, Two Scripts: The Hindi Movement in Nineteenth Century North India. Bombay: Oxford University Press.

Lal, Lallu. 1867. Prem Sagar; or The Ocean of Love. Translated by Edward B. Eastwick. London: W.H. Allen \& co.

Misr, Chutoorbhooj. 1842. The Prem Sagur or The History of Krishnu, According tothe tenth chapter of the Bhagubut of Vyasudevu. Translated by Lulloo Lal. Calcutta: Published for the Proprietors and to be had of all the Booksellers, in Calcutta.

Misr, Chutoorbhooj. 1848. The Prem Sagur. Translated by Captain W. Hollings. Calcutta: W. Ridsdale, Military Orphan Press.

RAI, AlOK. 2001. Hindi Nationalism. Hyderabad: Orient Longman. 